\title{
ON SOME EXAMPLES OF THE DIFFERENT TYPES OF GEOLOGICAL DEPOSITS.
}

\author{
Being an Address delivered at the Annual Meeting of the Geologists' Association on \\ February 5 th, 3904 , with which is incorporated the substance of a \\ Lecture delivered at the Meeting of the Association \\ on December 4 th, 1903.
}

By the President, hoRAce WOOllaston MONCKTON, F.L.S., F.g.S.

I WAS greatly interested by a paper which Mons. E. Renevier brought before the International Geological Congress at Zurich in 1894. It was entitled Chronographe Géologique, and the sedimentary formations were separated into groups-aerial, limnal, estuarial, etc.

During the last few years the Association has visited a number of sections in a great variety of geological formations, and I have had an opportunity of considering his classification so far as it relates to our British deposits, and I think that perhaps some of my notes on the subject may interest you.

I propose to follow Renevier and to divide the sedimentary formations into the following nine groups:-

Deposits not of Marine Origin.

I. Subaerial.

2. Fresh-water.

3. Estuarine.

4. Lagoon.

Detrital Deposits formed in the Sta.

5. Coastal deposits corresponding to the Littoral, and Laminarian zones of the Zoologists and to some extent including the Coralline zone.

6. Bathial deposits corresponding to the fourth bathymetric zone of the Zoologists, and probably sometimes including the third or Coralline zone.

Organic Deposits formed in the Sea.

7. Pelagic type.

8. Coral Reefs.

9. Abyssal formations.

\section{CLASS I.-SUBAERIAI, DEPOSITS.}

BLown SAND.-Of the subaerial deposits blown sand has attracted a good deal of attention in this country, for on many of our coasts it has proved exceedingly destructive. Thus the 
Barony of Culbin, on the Moray Firth, has been completely covered by blown sand.

I may remind you of the extensive sand dunes which we saw on March 29th, 1902, around Penard Castle, in Gower, which extended up the rocky slope to a considerable height; and of the long ridge of blown sand on the Northumberland coast at Scremerston, where we spent August $3^{\text {rd }}$ of last year.

These were both good examples of sand dunes, but those of us who attended the meeting of the British Association, at Southport, last September, saw sand dunes on a much larger scale. The foreshore there presents a wide expanse of sand at low water, and, as it dries, the wind blows the sand inshore and piles it up into dunes.

There are many sections in the dunes showing that they are well stratified and false bedded. The bedding was, no doubt, originally parallel to the surface, and as the wind changed in direction the false bedding was produced. Land shells and rabbit bones abound, and there are also many fragments of marine shells which have been blown inland. We are told that at the base of the older dunes there is a stratified deposit with Bythinia tentaculata and other fresh-water shells, where the sand has been blown on to marshy ground.

It has been suggested that various breccias may very probably be of subaerial origin, and that some of the finer materials may be windborne. (See Prof. Bonney, "On the Relation of Certain Breccias to the Physical Geography of their Age," Quart. Journ. Geol. Soc, voil. Iviii, p. 185). Possibly, the Triassic Conglomerate which we saw at Port Eynon, in Gower, at Easter, r 902, may come into this class of deposit. It did not appear to be stratified, and consisted of blocks and pebbles of limestone and chert, the different sizes mingled together. The conglomerate rested on the upturned edges of the Bishopstone Beds, which are of Carboniferous age.

Last August we saw a similar deposit between Burnmouth and Berwick-on-Tweed. It also consisted of an unstratified mass of stones of various sizes up to and, I think, at times, over three feet in diameter. It belongs to the Upper Old Red Sandstone.

Mr. Goodchild, who was our Director on the occasion, said he thought that the conglomerate was due to powerful torrential action, and he believed that the whole of the Upper Old Red Sandstone was formed during the prevalence of desert conditions, at a time when the land stood some height above sea level. In confirmation of his view, he stated that the sandstone in the formation was much false bedded, that casts of desiccation cracks and rain-pitted surfaces were common, and that he had found grains of desert sand on several horizons (ante, p. I19).

With regard to the I.ower (Caledonian) Old Red Sandstone, 
Mr. Goodchild thinks that it was also accumulated under continental conditions, and is largely due to torrential rain.*

Bone Breccia and Head.- Much of the breccia with bones found in caves should be classed with the subaerial deposits. We saw an excellent example at Bacon Hole, in Gower (Easter, 1902). There was on the floor of that cave a great pile of limestone débris cemented by carbonate of lime. Some of the material had, no doubt, fallen from the roof of the cave, but I think that the greater part had come from above through a great swallow hole, now cut through by the sea.

The angular Head, which overlies the raised beach in Gower, is a very similar deposit and is also of subaerial origin. (See Proc, Geol. Assoc, vol, xvii, p. 367, fig. 55).

Perhaps I may here mention the rather extensive deposit of chalky hill-wash near Betchworth, to which Mr. Whitaker drew our attention on June $x_{4}$ th, 1902 .

Clay with Flints. - The Clay with Flints which covers so large an area of our chalk is another subaerial deposit. It is mainly due to the decomposition of the chalk under atmospheric action. $\uparrow$

Sarsen Stones. - The sarsen stones of the Bagshot District and probably those found in many other places belong, in my opinion, to the subaerial deposits. I believe them to be the relics of an old land surface, as I explained on the Aldershot Excursion last summer. (See ante, p. 184).

Rootlet Beds, Dirt Beds, etc. - We saw a very good example of a rootlet bed in the Pakefield Cliffs on April 4th, I893. It consisted of clay, brown at the top but blue below, and it was full of rootlets, with a flint pebble or an unworn flint here and there. There was but little sign of stratification.

Clearly this was a land surface, and it belonged to the time of the Cromer Forest Bed Series. The Forest Bed itself is of estuarine origin, but the upper surface is in many places weathered and penetrated by roots. Mr. Clement Reid thinks there may possibly be a second land surface on the top of the Weybourn Crag, beneath the Forest Bed Series. +

Another example of a land surface is found in the Hamstead Series. The "Black Band" consists of about two feet of carbonaceous laminated clay with fresh-water shells and plant remains, and has been traced over a large area in the Isle of Wight. It rests upon a weathered surface of Bembridge Marl full of roots, and Mr. Clement Reid observes that this surface is well marked in borings, which after passing through unweathered Hamstead Beds penetrate a carbonaceous soll and then enter a

\footnotetext{
- Fauna, etc., of the Clyde Area, Brit. Assoc., Glasgow, 19or, p. ${ }_{4} 63$.

+ See Whitaker, Geol of Landon, Mem. Geol. Survev, 1889 , vol, i, p. 281 $\ddagger$ Geol. of Cromer, Ment. Geol. Survey, 1882, p. 22 .
} 
weathered clay full of roots, as in the surface soil many feet above.*

The Mammal Bed in the Middle Purbeck of Durleston Bay should, I think, be mentioned here. It is grey, earthy, about a foot thick, and from it many remains of marsupials have been obtained. I pointed it out when we were in Durleston Bay, at Easter, 1896 , but none of us found any remains of mammals.

The Dirt Beds at the bottom of the Lower Purbecks are also old land surfaces. At Easter, 1889 , we saw the Dirt Beds of the Isle of Portland, so well known from Lyell's illustration, showing tree-stumps and roots. And at Easter, 1898, we visited the quarries in the Purbecks and Portlands at Portisham Hill, near Abbotsbury. You may remember that we saw two large fragments of trees-one horizontal and over six feet long, the other vertical with spreading roots. We again saw one or more dirt beds close to the bottom of the Lower Purbeck, last Easter, in the quarry on the Teffont side of the Chilmark Ravine in the Vale of Wardour.

These Dirt Beds are relics of the land surface of the Purbeck Continent; a marine formation was, however, at the time in progress in East Yorkshire, and the Speeton Clay records the continuance of the sea there during the whole of the Purbeck and Portland periods.

When I gave a lecture on this subject, last December, Dr. Skeats reminded us of the quarry at Mount Sorrel, which some of our members "had an opportunity" of visiting during our Whitsuntide excursion of 1902 .

Prof. Watts on that occasion drew attention to the junction of the granite with the overlying trias, showing what he felt sure was the effect of wind erosion on the granite surface before the trias was deposited upon it (Proc. Geol. Assoc., vol. xvii, p. 379, and Plate xviii). This eroded surface should accordingly be placed amongst the pre-triassic land surfaces.

In the Coal Measures we have sun-cracks, marks of raindrops, footprints, and roots in situ, all of which are evidence of land surfaces. The present opinion seems, however, to be that the coal seams themselves were deposited in water, for, though branching rootlets are common in the underclays, it does not follow that they are the soil upon which the coal grew.

Glacial Deposits.--I think that several of our members will agree with me in thinking that we have seen subaerial deposits of glacial origin during recent years, but the subject is a large one, and I will not go into it this evening, more especially as it is one upon which I rather think that British Geologists are not yet quite agreed.

Volcanic Deposits.-We have, during recent years, seen many examples of volcanic deposits. They are frequently

* Geol, of the Isle of Wight, Mom. Geol. Survey, i887, p. Igo. 
stratified, the material appearing to have fallen into and been arranged by flowing water or currents. Volcanic eruptions are, however, often accompanied by the discharge of water, and on the whole it seems most convenient to class the volcanic deposits with the subaerial formations.

In May, 190z, during our excursion to Charnwood Forest, we saw some magnificent sections in volcanic agglomerate at the crags near Grace Dieu and Charnwood Lodge Drive. In some cases the rock seemed to consist of volcanic bombs and fragments, often of large size, buried in volcanic dust. I noticed blocks three feet across. On July 29 th last we saw something of the volcanic series of the Cheviot Hills. It is of the age of the Caledonian Old Red Sandstone. We walked up the side of a small stream, the Common Burn, and saw sections in :-

I. Bedded lavas (andesites) altered in places probably by contact with the Cheviot granite.

2. Dykes and sills of porphyrite cutting through the lavas. These Mr. Goodchild thought were ofishoots from the granite.

3. The Cheviot granite.

On the 28 th of July we saw, at St. Abb's Head, a series of rocks which, though mapped as intrusive, are now known to be lavas. They belong to a different volcanic area to those of the Cheviots, and in this case the whole series has been cut through by the sea, giving a magnificent section.

We walked from Coldingham Shore across the low ground inland of the Head to a small cove, where we saw on the shore the Silurian greywacke, greatly folded on one side, and a bed of andesite, one of a series of lava flows, on the other side of the landing place. There are, in fact, three of these lava sheets separated by stratified tuffs and conglomerate.

You may remember the tuff in another small cove where we lunched during heavy rain. The structure of the tuff or conglomerate was very well shown in the pebbles from it which covered the beach. After lunch we, or some of us, climbed down to the shore at another place and got specimens from a dyke of lamprophyre which cuts the volcanic rocks, and was well seen at the bottom of the cliff. This volcanic series is believed to be about $\mathrm{I}, 000$ feet thick.

On both these days we had a good opportunity of studying lava flows, but we only saw tuffs on a small scale. A little farther north, however, on the coast at. Dunbar and North Berwick, the cliffs afford admirable sections in the fragmental volcanic formations. Up to the present we have not visited those places, but I think we might well do so some day, for I have found them of the greatest interest.

The material was probably ejected from the three large necks, 
Traprain Law, North Berwick Law, and the Bass Rock. The first of these necks is formed of phonolite, and the other two of trachyte, and they themselves are well worth a visit.

The cliffs show sections in tuff and conglomerate, and in many parts the whole cliff is composed of those rocks. The blocks in the conglomerate are often very large, one seven feet across is mentioned in the memoir on Sheet 33, Scotland. In places the tuff is stratified, and here and there sedimentary beds occur. Some limestone has been worked near North Berwick, but I do not think that any marine remains have been found in it, and I fancy that the volcanic material was either thrown on to the land or into lakes or lagoons.

The blocks in the conglomerate are of igneous rock, shale, cementstone, limestone, \&c. The date of the eruptions was a little before the beginning of the deposition of the Carboniferous Limestone Series.

\section{CLASS 1I.-FRESH-WATER DEPOSITS.}

In this class I shall attempt to include deposits in rivers down to their estuary, in inland lakes which are not salt, and marsh deposits which cannot fairly be said to be of subaerial origin.

On April zoth, IgOI, we visited a remarkably fine series of sections in the recent deposits of the River Lea, between Tottenham and Higham Hill. The Report of the excursion was by Mr. A. S. Kennard, and not by myself as was stated by mistake, and I shall be glad if members will make the correction in their copy of the Proceedings (vol. xvii, p. 1 35).

The Alluvium at this point is half a mile wide, but it broadens out to about a mile a little to the north where a tributary stream from Epping Forest joins the Lea. The surface of the ground is very flat, with a level of about 25 feet above the sea. On the east the Alluvium is bounded by London Clay, and on the west by River Gravel, both of which rise from beneath it.

The surface was formed of a bed of silt with mud, peat, and dark clay, in places as much as ten feet thick. Below the peaty bed there was a bed of gravel, the bottom of which we did not see. This gravel was well-stratified, current-bedded, and in one place rose up nearly to the surface. Here and there a little peat occurred in the gravel.

In several places there were beds of light-coloured shell marl in the peat, and Mr. Kennard mentions that in one place he noticed a patch in the gravel. These beds of shell marl were lenticular, with a maximum thickness of about a foot. They were not all on the same horizon, and no doubt owed their position to alterations in the course of the river. The shells were of land and fresh-water species. It will be noticed that the 
river had excavated a valley here. It then ceased to excavate, having, no doubt, got nearly to sea level, and began to deposit coarse material forming gravel. Finally, for reasons upon which I need not now enter, a period of repose set in, and the river has been depositing fine material and vegetable débris, and has thus formed the dark-peaty bed. A shell marl of the type found here would, in process of time, possibly be converted into a limestone.

During our Easter excursion of 1896 we visited the deposit of calcareous tufa at Blashenwell, near Corfe Castle. It is believed to be of Neolithic age, and contains many land shells. Perhaps I ought to class it with the subaerial rather than with the freshwater deposits.

Calcareous beds of fresh-water origin form an important feature in the Oligocene Series of the Isle of Wight. At Whitecliff Bay the Bembridge Limestone is about twenty-five feet thick, and contains both land and fresh-water shells. Several specimens of Helix vectensis were found by members of our party at Easter, I 895. In the middle of the limestone there is about three feet of carbonaceous clay, probably of estuarine origin, as it contains Cyrena obtusa with the valves united. In both the Upper and Lower Headon there are beds of limestone with fresh-water shells Limnæa, Planorbis, Paludina, \&c.

Mr. Hudleston has recently discovered what he believes to be a fresh-water limestone of Eocene age at Creech Barrow, near Corfe Castle.*

The Paludina-Bed, which is found in the middle of the Woolwich Series, should be classed with the fresh-water limestones. It is a calcareous stone, at times rather clayey, and is usually full of fresh-water fossils. It extends over a considerable area and has been recorded at Peckham, New Cross, and Chiselhurst.

We saw the bed exposed in the Sundridge cutting on the South Eastern Railway on July $28 \mathrm{th}$, I900. It consisted of a compact mass of Paludinæ.

It was again seen by the members of the Association in the re-opened cutting of the London and Brighton Railway at New Cross on April 18th, I903, when Paludina, Unio, and a few specimens of Pitharella Rickmanni were found; and again, near Crofton Park on April 25th, 1903, where it contained merely a few specimens of Paludina. (See Proc. Geol. Assoc., vol. xviii, p. I62).

The Purbeck Marble at Pevril Point, near Swanage, is a mass of the shells of Paludina, and is not unlike the Paludina Bed of the Woolwich Series on a large scale. The late Mr. Meyer considered that it had been deposited in quiet water, possibly in a lake.

\footnotetext{
*Proc. Dorset Nat. Hist., etc., Fiela Club, vol. xxiii, p. I 46 (1902).
} 
Some of the bands of limestone in the Coal Measures are probably of fresh-water origin, though I thought that our Directors at Whitsuntide seemed inclined to consider the Coal Measures less a fresh-water formation than we have usually supposed. (See Geol. of Stoke-upon-Trent, Mem. Geol. Survey, rgoz, p. 39).

During recent years we have paid many visits to the brickfields near Crayford and Grays, and though some of the sections are not as fine as they used to be, they are still very well worth study. The deposits consist of brickearth, sand, and gravel, and contain Corbicula fluminalis, Unio littoralis, and other land and fresh-water shells.

The brickearth is usually very evenly bedded, and in places one can see that alterations in the course of the river have taken place, the stream having cut down into the bed previously deposited and produced current-bedding.

The sand and gravel is also current-bedded, and usually to a much greater extent than the brickearth.

The valley is cut in Chalk and Thanet Sand, and in places the river deposits may be seen banked up against the side of the old valley, and where the side of the valley is Chalk there is generally a good deal of chalk rubble between the valley deposit and the solid rock.

It is interesting to compare these Thames deposits with those in the buried valleys of the Yorkshire coast. Near Flamborough the old valleys are cut in Chalk, and there we find a similar chalk rubble at the sides of the valley.

The Yorkshire valleys are largely filled in with stratified sands and gravels, but as they are older than the local Boulder Clays they are partially filled in by those clays.

At Easter, in I893, we were fortunate enough to see the freshwater beds at Mundesley, near Cromer. The section is figured in Lyell's "Antiquity of Man," 4th Edition, 1873, pp. 268. The deposit rests in a valley cut in soft strata, belonging to the Glacial and Forest Bed Series. At the bottom there is some rather coarse gravel and upon it there is a dark bed of peat, sand, and more or less clayey silt. The thickness of this dark bed is about 30 feet. It contains roots, seeds, Anodonta cygnea, and other land and fresh-water fossils. Above it there is more gravel.

When we visited the locality in 1902 this part of the cliff section was hidden.

We have on two occasions recently visited the Hitchen Lake Bed (June 2oth, 1896 , and May 5 th, I900). It rests in a hollow cut in stratified and current-bedded gravel which is probably of Glacial age. The lake deposit consists of a soft calcareous sandy loam of various shades of brown. It is for the most part thinly and evenly stratified, and is full of shells and shell 
fragments of fresh-water molluscs. There is considerable thickness of brickearth above the lake bed.

I have not seen the Hoxne deposits, but judging by the published accounts they resemble those of Mundesley and Hitchen, and like them are newer than the Glacial Deposits of the district.

The celebrated deposit at Fisherton, near Salisbury, which we saw last Easter (1903), reminded me of the Thames deposits at Crayford and Grays, and also of those in the old valleys near Flamborough, for in all these cases there is a series of beds formed by a river banked up against the side of a valley, and in all it so happens that the side of the valley is wholly or partly of Chalk.

On May 26th, I894, we explored a series of brickfields on the high ground to the west of Luton. At a kiln south of Woodside we saw a good section showing a considerable thickness of brickearth and sand, with current-bedding in places.

At Caddington we saw other sections in well stratified brickearth, with layers of clay and of stones here and there. I think that this deposit is probably of fresh-water origin, possibly due to floods caused by melting ice during the latter part of the Glacial period.

The Sidestrand Unio-Bed between Cromer and Mundesley is a fresh-water deposit, older than the Boulder Clays of Norfolk, and belonging to the Forest Bed Series. It rests on the land surface at the top of the Forest Bed which I have already mentioned. At the bottom of the deposit is a gravel mainly composed of small subangular flints, and containing many single valves of Unio. Above there is a clayey bed with more Unio and other fresh-water shelis. I believe that this bed is not often exposed, but we were fortunate enough to see it and to be able to collect from it in I893, on the same lucky day on which we saw the Mundesley fresh-water bed. It was the first of April.

On the west of Cromer the fresh-water bed on the horizon of the Sidestrand Unio Bed consists of peat or peaty loam, often sandy at the bottom, and Mr. Clement Reid remarks that most of the small vertebrated remains and fresh-water shells for which this bed is celebrated have been obtained from Runton.

I have already mentioned the Black Band of the Hamstead Beds of the Isle of Wight as lying on an old land surface. It contains fresh-water shells, and at the bottom there is a layer with well-preserved Unio gibbsii. Much of the Lower Hamstead Series and, probably, some part of the Bembridge Marls is of fresh-water, perhaps mainly of lacustrine origin.

The Headon Limestones are, as I have said, of fresh-water origin, and some of the clayey beds also contain fresh-water fossils. You may remember a bed close to the bottom of the Lower Headon, in Whitecliff Bay, to which I drew your attention 
when we were there on April I 2 th, I 895. It is a dark clay with ironstone nodules, lignite, and great numbers of Paludinx. I consider it a typical fresh-water formation.

The light coloured sands and pipeclays which form the Bagshot Beds at Corfe, Studland, and between Poole and Bournemouth, are probably of fresh-water origin. It is true that bored wood is found in them, but, according to Mr. Starkie Gardner, bored wood is found a long way from the sea in some modern rivers. He considers this part of the Bagshot Series to have been deposited by a large river flowing from the west.

Between Poole and Bournemouth the cliff section shows sand with many lenticular patches of clay. The clay is usually of a light colour, but dark patches occur. In many of these clay patches impressions of leaves are abundant and beautifully preserved. Several of us obtained good specimens during our excursion at Easter, 1894.

The pipeclays at Corfe are fairly extensive, but the beds are possibly lenticular. They are probably of fresh-water origin.

The Bovey Tracy Beds are of Bagshot age and appear to have been deposited in a large lake. The Association visited the sections at Easter, I900, and the general appearance is well shown in the photograph reproduced in the Report of that excursion (Proc. Geol. Assoc, vol. xvi, Pl. I2). The deposit is very thick, and a boring was carried to a depth of 520 feet from the surface, through clays, sands, and lignites, without reaching the bottom.

The greater part of the Lower Bagshot of the Bagshot district appears to be without fossils, and may be of fresh-water origin. On May 3oth, $189 \mathrm{I}, \mathrm{Mr}$. Hudleston showed us a clayey deposit in this part of the Bagshot series, at Hatch, near Addlestone which seemed to be lenticular and was not unlike some of the fresh-water beds which I have mentioned.

'The Reading Beds in the Reading district consist of an upper division of mottled clay some thirty feet thick, and of a lower sandy division about twenty feet thick beneath which is the Bottom-bed, consisting of green sand and clay with green coated flints resting on the chalk.

This Bottom-bed is marine and the Basement-bed of the London Clay above the Reading Series is marine too, but I believe the whole of the intervening sands and mottled clays to be of fresh-water origin.

In the sands a little above the Bottom-bed there are some lenticular patches of ferruginous sand and grey laminated clay with leaves. One of these leaf beds was exposed in the great cutting on the Reading and Basingstoke Railway, and was described by Prestwich in 1854 .*

A leaf bed is reported to have been found on almost the same horizon by our members on June 3 rd, 1876 (" Record of

\footnotetext{
* Quart. Journ. Geol. Soc., vcl. x, p. 88.
} 
Excursions," p. 269) in the Waterloo brickfield on the western slope of Southern Hill, Reading. A leaf-bed, perhaps the same, was again exposed in the same brickfield in I88I and I collected specimens from it.

It was soon afterwards concealed by rubbish, and I did not see it again for several years, not, I think, until r $90 \mathrm{I}$, when Mr. Shrubsole showed it to me in a small excavation in the same brickfield and not far from the spot where I had seen it twenty years before. On May 31st, 1902, the Association visited this excavation and many specimens of leaves were obtained.

A leaf-bed on about the same horizon as that at Reading has been found by Mr. Treacher in a brickfield at Knowl Hill between Twyford and Maidenhead (see Report of Excursion on July 6th, 1901, Proc. Geol. Assoc., vol. xvii, p. 18r), and a similar bed has also been recorded at Shaw Kiln, Newbury.*

In the Isle of Mull some beds with ferns, etc., are found among the basalts. They are of very early Eocene age.

In the opinion of the late Mr. C. J. Meyer the Wealden and the greater part of the Purbecks are not purely fluviatile or estuarine but of fluvio-lacustrine origin. In support of this view he pointed to the apparently quiet deposition of most of the strata, the absence of shingle, and of drift wood perforated by mollusca. In the Wealden, he adds, there is an absence of banks of broken shells.

You may remember the cliff section in the Wealden which we saw near Sandown at Easter, 1895 , and I think you will agree that the beds of very thinly laminated shale full of Cyprids, with here and there layers of Paludina and Cyrena, did look very much like a lake deposit.

Large double shells of Unio are found in the Wealden, nearBrook Point, in the Isle of Wight, and an account of the celebrated pine raft there is given in the report of our excursion of Easter, r891. (Proc. Geol. Assoc., vol. xii, pp. 163.)

I have collected double shells of Unio from the Upper Purbeck of Pevril Point, and I think that formation is as a whole of fresh-water origin.

Probably the Purbeck below the Cinder Bed is mainly fresh-water, thus the thin splitting shales full of Cyrena, which we saw in the Teffont Quarry last Easter, and which I think belonged to the Lower Purbeck, are probably a fresh-water deposit, and so is the flint-bed a little below the Cinder Bed in Durlston Bay.

The late Mr. Godwin Austen expressed an opinion that every mass of red sandstone would ultimately be referred to either a brackish or fresh-water origin (Quarterly Journal of the Geological Society, 1871, vol. xxvii, pp. 198), and probably the greater part of the Keuper and Bunter, a good deal of the Permian, and

\footnotetext{
- Whitaker's Mem. Geol. Survey, vol. iv; p. 285. 
much of the Red Beds of the Coal Measures are of fresh-water or of lagoon origin.

I may remind you that $\mathrm{Mr}$. Walcot Gibson considers the red colour of the upper part of the coal series of Staffordshire to be original. I was a good deal surprised at the thickness of those red beds which we saw at Whitsuntide, I 903, but I am quite prepared to believe them to be fresh-water deposits. The Bunter, as we see it, is certainly not of marine origin, though $I$ think it quite possible that the pebbles may to some extent be derived from sea beaches of an older date.

The Bunter is rather variable as to the abundance or scarcity of pebbles. In the great pit which we saw in Trentham Park on June 2 nd, $19 \circ 3$, the formation consisted of a vast mass of pebbles with well developed current-bedding. Here and there the strata were sandy, and occasionally, usually in the sandy parts, there were hard bands. The colour was on the whole red, but a light greenish tint prevailed in places.

As a contrast to this section I may mention the rock upon which Nottingham Castle stands, and which also belongs to the Bunter Pebble Bed Series. Pebbles are, however, not abundant, and the rock is a light coloured sand and sandstone, with only here and there a reddish patch. A few pebbles are scattered throughout and in places there is a fairly continuous layer of them, but they are small and not often more than an inch long.

I ought not to leave the fresh-water deposits without mentioning the Elgin Sandstone, for though we have not visited any sections in it, the formation seems to be more especially connected in our minds with one of my predecessors in this chair, Mr. E. T. Newton, who described the wonderful reptiles found in that formation. The sandstone in question is one of the common building stones of North Scotland, and is largely quarried about Cummingstown and Lossiemouth.

\section{CLASS III.--ESTUARINE DEPOSITS.}

This section is intended to include the deposits in an estuary or delta where fresh water mingles with salt water. The fauna is consequently a mixed one, and includes fluvio-marine and brackish water forms.

In some cases the deposits near the mouth of a river are of great thickness. An estuary is at times an area of depression. probably because drainage has a tendency to flow towards such an area. Thus the estuary of the Rhine has been an area of depression for a long time, and more than 1,000 feet of strata have been deposited in Holland since the beginning of the Pliocene, as is shown in Mr. Harmer's diagram (Proc. Geol. Assoc., vol. xvii, p. 423 , fig. $6_{5}$ ). This area of depression has at times 
extended so as to include the east of England, and we find the evidence of this in our Crag. The Forest Bed appears to have been deposited when the land at Cromer stood at about its present level, though the relative levels of the adjoining areas were probably very different, and a large part of what is now the North Sea may have been land.

It seems to be now decided that the stumps of trees which have been found in such numbers in the Forest Bed are not on the spot on which they grew, but have drifted down a river, probably the River Rhine. The shells are of both marine and freshwater species, and the marine Mya truncata is found in the position of life, so we may safely call the Forest Bed an estuarine deposit.

On July 3oth, 1902, we visited a section in the Chillesford Clay close to the church at Chillesford, and our Director, Mr. Harmer, expressed an opinion that the clay was an estuarine deposit ; the fossils seem, however, to belong for the most part to marine species, and I feel inclined to think it better to place the Clay of Chillesford with the sea-coast deposits. It was, however, probably laid down near the mouth of a large river, the Rhine in fact, and perhaps the question is really where we are to say the estuary becomes sea? The Bembridge Marls are, as a whole, of estuarine origin and give a good example of a mixed fauna. Thus we find the fresh-water Limnæa and Paludina, and the marine Cytherea and oysters, whilst Cyrena obovata and Cyrena semistriata, which are estuarine shells, occur in great abundance. At St. Helens there is a marine band with Arca, Mya, Mytilus, and oysters. When we visited that locality, on April I6th, 1895, we collected from this marine band, and some of our party found specimens of the Arca.

The beds at Hengistbury Head, near Christchurch, Hants, belong to the Bracklesham Series, and are probably of estuarine origin. They contain large fragments of stems of trees and beds of ironstone. A dark clay near Boscombe, also of Bracklesham age, contains similar large blocks of wood, and many were lying on the shore when we visited the place at Easter, 1894. Our Director, Mr. Starkie Gardner, said he had found sharks' teeth in the same bed, and that the wood at that place and also at Hengistbury Head was bored by Teredo.

Honeycomb Chine at Boscombe has been excavated in white and grey sand evenly and horizontally stratified. One band is full of empty husks of the fruit Nipadites. The allied genus Nipa lives at the mouth of rivers in places liable to be flooded by sea or brackish water.

The Woolwich Beds are mainly of estuarine origin in the neighbourhood of London, but become more marine as we follow them to the east. At Erith the intermediate type prevails.

The finest section which $I$ have seen in this series was in the 
railway cutting near Croydon, which the Association visited on June 2nd, I883. I think it was the first excursion of the Association which I attended. The mottled clay of the Reading Beds was well developed, and above it there were some beds mainly of estuarine character and with a total thickness of about ten feet. The fossils included Paludina, Planorbis, and Cyrena, and an uyster bed was closely connected with the strata in which the above fossils were found, so that there can be little doubt as to the estuarine character of the whole.

On June I $5^{\text {th, }}$ I90I, we saw another magnificent section through the Woolwich and Reading Beds at Orpington, on the South Eastern Railway. The details will be found in the report of the excursion by Mr. Holmes. (Proc. Geol. Assoc., vol. xvii, p. 169.)

The mottled clays, which I believe to be of fresh-water origin, were replaced by a series of evenly stratified clayey beds containing an abundance of estuarine shells. In the upper part were some layers with oysters, and the lower part was pebbly.

At Upnor, which I visited with the Association on June 6th, I89r, there is another good section in the Woolwich and Reading. Series. There was no mottled clay, but the beds were estuarine and possibly in part marine, for there is no doubt that we get nearer the mouth of the Woolwich and Reading river as we go eastwards. The section is given by Prestwich (Quarterly Journal of the Geological Society, vol. x, p. Io7). I did not see his bed (c) at the top of the series, but (b), a finely laminated clay full of estuarine shells and with selenite, was well shown. Below it was a considerable thickness, perhaps 20 feet, of very white sand, with current-bedding in places and black pebbles at the bottom. The pebble bed was often a mere layer, but in one place it was six inches thick. The pebbles rested on the top of the Thanet Sand.

The Oolites are, on the whole, of marine origin, but estuarine beds are by no mearis absent. I may remind you of a very interesting day which we spent amongst the workings for ironore, near Wellingborough, in Northamptonshire (April 28th, I894).

A photograph of the section at Finedon Hill is reproduced (Proc. Geol. Assoc., vol. xiii, Pl. vii).

The series shown was as follows:

I. Limestones with a little clay containing Rhynchonella and other marine fossils.

2. Clayey beds with plant remains, vertical stems in places suggesting quite shallow water. (Upper Estuarine Bed.)

3. A series of limestones, with a little marl, \&c., containing the estuarine Cyrena and also marine shells.

4. Sands without fossils, believed to represent the Lincolnshire Oolite. 
5. Sands and clays with much carbonaceous matter, and again with vertical plant markings. (Lower Estuarine Bed.)

6. The Northampton Iron-ore Series.

In Yorkshire the estuarine phase is far more fully developed, and the greater part of the formations between the Cornbrash and the Lias are of estuarine origin. They are mainly sands with much current-bedding, and nodular beds with iron-ore occur in places. A few plants have been recorded from the Upper Estuarine Series, and in the Middle Series there is the wellknown plant-bed at the northern end of Gristhorpe Bay; and in the Lower Series plant remains have also been found, and there are some thin beds of coal. Amongst these Yorkshire Estuarine Beds there are a few marine bands, mostly limestones.

The Coal Measures are, probably, to a considerable extent of estuarine origin. It appears now to be considered that the coal seams themselves are not the remains of forests in place of growth, but that the vegetable material of which they are formed has been, more or less, drifted, and that the seams should be classed with fresh-water or estuarine deposits-perhaps, most often, with the latter.

The limestone termed Spirorbis Limestone has usually been regarded as of fresh-water origin, but our Directors at Stoke-onTrent, last Whitsuntide, remarked that Spirorbis is common in the marine part of the Coal Measures.

At Scremerston, on the Northumberland coast, the coal seams seemed to be very closely associated with limestones containing an abundance of corals, and, evidently, of marine origin.

In Scotland a large part of the Carboniferous System consists of the series which has been termed the Calciferous Sandstone, and it is, I think, in the main estuarine.

Dr. Traquair remarks ("Trans. Roy. Soc. Edinb., vol. xl, p. 688) that this series is, in the Edinburgh District, characterised by the rarity of marine beds, the principal limestone, that of Burdiehouse, being of estuarine origin, like the sandstones, shales, and ironstones which form the mass of the series.

The fossil trees of Craigleith Quarry have long been celebrated, they are not however I think in place of growth, but have probably drifted down a river. The trees are in sandstone and above the sandstone are the Wardie Shales which have furnished a rich fish fauna. Dr. Traquair says that the shales are estuarine though they contain some bands with Myalina, Schizodus, Lingula, etc., but with no hinged Brachiopods (Trans. Roy. Soc. Edinb., vol. xl, p. 690).

The oil shale which forms so important a feature in the 
Calciferous Sandstone Series of the Edinburgh District is not unlike the Kimeridge Coal, but its origin is different, for the Kimeridge Coal is a marine formation deposited probably in deepish water, whereas the Edinburgh oil shale is probably of estuarine origin.

\section{CLASS IV.-LAGOON DEPOSITS.}

This division is intended to include deposits in sheets of water where salt has become concentrated by evaporation. Such deposits have been termed Caspian and are characterised by the presence of gypsum and salt. Animal remains are naturally scarce or absent. In the Paris Basin there are beds of Eocene age belonging to this class. I refer to the dolomitic beds in the Upper Calcaire Grossier and the gypsum beds of Montmartre.

In this country the Lower Purbeck is probably to a great extent a lagoon deposit. On April 4th, 1896, we saw some large concretionary masses of gypsum in the beds of that age in Durlston Bay, Swanage, and last Easter (1903) in a quarry near Ridge in the Vale of Wardour several of us found good examples of the hollows left by crystals of rock salt.

Rock salt and gypsum are found in the Keuper and that formation is probably for the most part a lagoon deposit.

The Bunter may also belong to the present class and the Permian was probably deposited in salt lakes, though the sea must have had access to the area during Magnesian Limestone times, for it contains Productus and other Brachiopods. At the same time fossils are not common in the Magnesian Limestone and I have searched in many of the large quarries in Nottinghamshire without finding a sign of a shell. Perhaps it was deposited in a sheet of water connected with the sea rather than in open sea.

During our excursions to Scotland in 1897 and 1903 we heard a great deal about the Ballagan Beds, and we saw a very good section in them in the cliffs near Burnmouth, July 3oth, I903. They consisted of sandstone showing current-bedding in places with some clays and shales and bands of cement stone.

Mr. Goodchild told us he had seen surfaces with suncracks, and also pseudomorphs after rock salt and deposits of gypsum suggesting shallow lagoons which dried up from time to time.

The Ballagan Beds are near the bottom of the Carboniferous Series and belong to the Calciferous Sandstone Group, which, as $I$ have already mentioned, is largely estuarine.

The Old Red Sandstone is usually regarded as a lake or lagoon deposit, though it may be to some extent of terrestrial origin. 


\section{CLASS V.-COASTAL DEPOSITS.}

i. The Sea ShORe.-We have, amongst our geological formations, plenty of examples of deposits formed on or close to the sea shore. They consist of both coarse and fine material, sometimes arenaceous and sometimes calcareous. In the latter case the lime may be derived from adjoining cliffs or from shells, etc.

The Raised Beach of Gower, which we saw at Easter, 1902, is a good example of a detrital limestone deposit of marine origin. It consists chiefly of pebbles of the Carboniferous Limestone Rock of the coast. Shells more or less broken are common, and at one place in Port Eynon Bay we saw a considerable mass of shells and shell débris. 'Though the pebbles were mostly limestone, other rocks were not uncommon, and in some places I noticed a good many sandstone pebbles.

The Weybourn Crag is, I should say, a coastal deposit formed very near the shore. It was well exposed in the cliff at Weybourn at the time of our visits on April 3 rd, 1893 and on August 4th, 1902. The bed was light coloured, sandy and chalky, with black subangular flints and also flint pebbles. There were several patches of shells, single valves of Tellina balthica abounded. And I noted many specimens of Cardium edule, also single valves, and Littorina littorea.

During the Easter excursion of 1893 we "had an opportunity" of visiting a fine section in the Bure Valley Beds, at Coltishall. They consisted of ferruginous gravel and currentbedded sand, with, in one place, a little laminated clay. Probably the whole was a coastal deposit formed near the shore, and, also probably, near the mouth of a large river.

The "Mammaliferous Crag" of Norwich has been classed with the estuarine deposits. Mr. Harmer, however, speaking of it as the Norwich Crag, told us that he considered it to be marine-though accumulated near the mouth of a river (Proc. Geol. Assoc., vol. xvii, p. 446).

We spent a considerable time in the pit at Thorpe Kiln, near Norwich, on March 31st, 1893, and I collected many fossils and made a note of the section. The "Mammaliferous Stone Bed" is an accumulation of large flints, which have been but little water-worn, and a little clay. I found a few shells in the bed.

It rests on the chalk and forms a basement bed to the Norwich Crag at this place. It differs from the Suffolk Bone Bed, for I did not see any phosphatic nodules in it, though we were told a few occur. It is more like the bottom bed of the Reading Series, but the flints are more rolled. On the whole, I see no reason for separating the Stone Bed from the overlying sandy Norwich 
Crag, and I should think it is of marine origin and accumulated near the shore.

The overlying sands are current-bedded and crowded with marine shells, the bivalves being mostly single valves, and many of the shells are waterworn. I should say, also, a coastal marine deposit near the shore.

The Red Crag is a coastal deposit formed, I think, close to the shore. It is very much current-bedded, the bivalves usually occur as single valves, and pebbles are common.

Prestwich found an actual shore-line in a pit near Wood Hall, Sutton. (See Quart. Journ. Geol. Assoc., vol. xxvii (187 r), p. 340.)

We spent some time in the pit on July 29 th, rgo2, but the section was not very clear, still we could see the Coralline Crag which formed the shore of the Red Crag Sea, and close by, in the same pit, we found the fossiliferous Red Crag itself. (See Proc. Geol. Assoc, vol. xvii, p. 48r.)

In the Bracklesham Beds of Whitecliff Bay there is one bed, No. I3, of Prestwich's section, which I believe to have been deposited close to the shore, for it is full of broken and waterworn shells as well as pebbles. (See Proc. Geol. Assoc., vol. xiv., p. 100.)

The Basement Bed of the London Clay is a marine coastal deposit succeeding to the fresh-water mottled clays of the Reading Beds, and preceding the London Clay, which belongs to the next or Bathial Class of Deposits.

At Reading, where we have often seen the Basement Bed, it consists of sand and clayey sand with a few pebbles, and layers of Ditrupa plana, and marine shells. Pectunculus, Cytherea, and Protocardium are the commonest bivalves, and they usually, but not always, occur as single valves.

We saw a good example of a pebbly coast deposit of Eocene age in the cuttings on the South Eastern Railway at Sundridge Park, Chiselhurst. The Woolwich Beds at that place are, as I have said, of freshwater or estuarine origin, but in Oldhaven times the sea advanced over the area south and south-east of London, and at Sundridge Park had cut into the Woolwich Beds, so that at the Chiselhurst end of the section the Oldhaven Beds rest on the bottom bed of the Woolwich Series. (See Whitaker, London, vol. i, p. 227.)

The Oldhaven Beds consisted of sand and pebbles, the whole much current-bedded. In places there were numerous irregular layers of calcareous concretions and in most cases these were full of shells. Towards the eastern end of the section masses of oysters occurred and also collections of Cyrena. In other parts of the section the most common fossil was the marine shell Pectunculus, usually single valves, piled together in the most irregular manner one inside another. 
ii. Oyster Beds.-Beds of oysters are found at many geological horizons. There is a good example in the marine part of the Middle Headon of Colwell Bay. (See Report of the Excursion on April I5th, 1895, Proc. Geol. Assoc,, vol. xiv, p. I 10.) I have already mentioned oyster beds in the Oldhaven and amongst the shell beds of the Woolwich Series. I noted examples in the latter formation in the railway cuttings at Park Hill, Croydon, and at Orpington, and Mr. Whitaker mentions others at Charlton, etc. (See "Geology of London," vol. i, pp. I $47-8$, etc.)

There is frequently a layer of Ostrea bellovacina in the bottom-bed of the Reading Series. At Reading it is a very marked feature and the oysters usually have the valves united. In one place there are two layers of oysters; they lie in a green sand, with a few pebbles, and sometimes there are also sharks' teeth and a few marine shells. The green sand rests on the Chalk, and at the bottom there are numerous green-coated flints which have not been rolled or waterworn.

I almost think that the layers of Exogyra conica in the Upper Greensand at Punfield Cove, near Swanage, may be included with the oyster beds. Associated with the Exogyra I have found many bivalves with closed valves which probably lived on the spot. I may mention Cucullaa glabra, Pecten orbicularis, Pecten asper, and Spondylus striatus.

The Cinder Bed of the Middle Purbeck is an oyster bed. We saw it in the quarry near Teffont Church last Easter (1903). It was about a foot thick and consisted of a grey limestone full of shells of Ostrea distorta. At Lady Down, too, the Cinder Bed was weil marked in the quarry in which we sheltered (?) and lunched during a snowstorm. At Swanage, 42 miles south of Teffont, the Cinder Bed is well developed, and in Durlston Bay it attains a thickness of between 8 and 9 feet. It is there a compact mass of shells of the oyster, amongst which are a few specimens of Cardium, Perna, and Trigonia ; together with the spines and plates of Hemicidaris purbeckensis.

The Cinder Bed is also found at Upway, north of Weymouth, 24 miles west of Durlston Bay and 47 miles south-west of Teffont.

The Perna Bed near the top of the Portlandian may be classed with the oyster beds. At Tilly Whim, near Swanage, it is about 12 feet thick and is a mass of shells of Perna bouchardi. On our excursion to Swanage, at Easter, 1896 , we saw the bed in several quarries along the coast from Tilly Whim to St. Albans Head.

Mr. H. B. Woodward mentions a bank almost entirely composed of Ostrea acuminata in the Fuller's Earth Series;on the borders of the Fleet south of Langton Herring, near Weymouth ("Geology of England and Wales," znd edit., p. 296). 
I feel inclined to place the Scarborough Limestone amongst the oyster beds. The formation is closely connected with the thick estuarine series, above and below it, and Mr. Hudleston mentions ripple-marked slabs in the limestone at Hundale Point (Proc. Geol. Assoc., vol. iii, p. 313); it was consequently formed near the shore, and in places there are layers of Avicula braamburiensis and other layers of Gervillia acuta.

I do not suggest that all the above which I have placed together as oyster beds were formed in shallow water. I fancy that the oyster and its allies like a good current, and that, given the current, an oyster bed may be formed at a considerable depth.

iii. Shallow Water Near the Sea Shore.-We have a number of current-bedded, sandy deposits which contain marine fossils, the valves of the bivalves being sometimes single and sometimes united. I may mention the Coralline Crag, the Barton and Bracklesham, the Lower Greensand, the Forest Marble, Stonesfield Slate, and Millstone Grit, as all coming to some extent within the above terms, and to that extent, 1 think, they were probably formed fairly near the shore and should be classed with the coastal deposits.

iv. Deep Water Near the Sea Shore.-There are other geological formations which, though they contain fossils of much the same genera, and even species, as the deposits mentioned above, differ from them in being seldom current-bedded, and have probably been deposited in still and rather deep water, though not far from the shore. These formations are formed of detrital matter, whether they be arenaceous or calcareous, the fossils are all marine, are not crushed, and the valves of the bivalves are usually united and closed.

The Barton or Upper Bagshot Beds of the London Basin are a good example. We saw a section in them at Tunnel Hill, near Aldershot, on June 6th, iro3. They consist of yellow sand, there is no current-bedding, in fact, very little sign of bedding at all. The fossils occur as casts only, but the genera and even species can often be identified.

The following bivalves are fairly common and have the valves united: Cardita, Corbula, Crassatella, Cytherea, Lucina, Nucula, Pecten, Pectunculus, Protocardium, Strigilla, Tellina, and the little Ostrea plicata. These sands were probably deposited in a wide bay or open sea not far from land.

The Thanet Sands are another example of this class. When we were at Upnor on June 6th, I89I, I noticed that they were yellow and white sands in thick massive beds, and that they differed markedly from the current-bedded sands of the Woolwich Series above them in the same section.

The Portland Series belongs mainly to this class of deposit. At Wockley, in the Vale of Wardour, we saw a good section in 
its upper part and its junction with the overlying Purbecks. Near the top of the Portlands there was a bed full of fossils, amongst them I noticed a great number of Pecten lamellosus, which appeared to have lived on the spot, for the shells were not waterworn and the valves were united and closed.

Near Swanage, too, the shells of Cardium, Cyprina, and Pleuromya, in the Portlands, are generally in good condition, with united and closed valves. The big Portlandian Ammonites appear to have lain for some time as dead shells on the sea bottom, for there are signs that oysters lived inside them before they became filled with the calcareous mud.

The Kellaways Rock is a phase of the Oxfordian which bears considerable resemblance to the Upper Bagshot and Thanet Beds. On our Whitsuntide excursion of 1896 we saw a section in the rock at Kellaways itself, and I collected many specimens of Myacites recurvus as well as a number of Rhynchonella and Waldheimia with the valves united and closed. In the same formation in Yorkshire I have found specimens of a large Pholadomya, of Gervilleia, and of other bivalves in a similar condition.

The Inferior Oolite is probably to a large extent composed of the waste from coral reefs, and both it and the Midford Sands probably belong to the class of deposit with which I am now dealing.

\section{CLASS VI.-BATHIAL DEPOSITS.}

I now come to a series of clays, shales, marls, \&c., probably deposited in deeper waters than any in the last class, and to some extent corresponding to the fourth bathymetric zone of the zoologists.

Brachiopods are usually abundant, and there are great numbers of the shells of animals, such as Ammonites, which live near the surface of the seá.

In many cases deposition appears to have been fairly rapid, for beds of crushed Ammonites, \&c., are a common feature in this class of deposit. These shells were probably buried before the decay of the animal had allowed the sediment to fill the interior of the shell, and the shell consequently was crushed by subsequent pressure. In many cases the outer chambers of the larger Ammonites had become full of sediment and have been preserved from crushing, whilst the inner chambers of the same shell have been crushed.

In the Middle Headon, Barton, and Bracklesham formations we find clayey beds full of marine fossils with many double bivalve shells, and probably these should be to some extent included in the bathial class, or, perhaps, we should consider them as intermediate between the coastal and the bathial 
deposits. They were most probably laid down in the sea in deepish water and at no great distance from the mouth of a large river.

The London Clay may well have been deposited in a tract of sea, such as the German ocean, fifty or a hundred miles off Harwich. The fossils are for the most part marine, and the bivalves are generally double. The genera are not as a rule deep-water forms, and at Sheppey and Harwich numerous remains of turtles and fruits and seeds show that the mouth of a large river was at no great distance.

The Chloritic Marl, Upper Greensand and Gault may, I think, be classed, to a large extent, with the bathial deposits, though part of the Upper Greensand should, I think, go into the coastal class.

The sea extended over East Yorkshire during Purbeck and Wealden times, when so much of our jsland was land, and in consequence we get in Yorkshire a continuous series of clays crowded with Ammonites and other marine shells. It is known as the Speeton Series, and is a bathial deposit.

The Kimeridge Clay also belongs to the present class and was deposited during a time of extensive submergence, when the sea stretched from Normandy to Yorkshire; though, probably, there was land in our south-eastern counties and also in Cornwall and Wales.

The Ampthill Clay, the Oxford Clay, and the greater part of the Lias belong to the bathial class, and, possibly, I should add the Fuller's Earth.

In the Carboniferous there are some fairly thick beds of shale with an abundance of Cephalopods and Brachiopods, which I am inclined to class with the above clays.

You may remember the gannister quarry in the Congleton District, which we visited on June 8th last (1903). I was much struck by the abundance of Brachiopods in the shales. One bed about five feet thick was a mass of the shells of Orthis resupinata. The beds belong to the Pendleside Series.

In Gower, on March 31st, I902, we collected Gonatites from dark shales belonging to the Gower Series, probably of Millstone Grit age. The shells were very numerous and were crushed, and reminded me of the shales with crushed Ammonites which we have seen in the Kimeridge Clay.

I think we should probably class the Graptolite Shales of the Silurian and Ordovician with the bathial deposits.

\section{CLASS VII.-PELAGIC DEPOSITS.}

These deposits were accumulated too far from the shore for them to contain more than a trace of detrital sediment, and they 
are consequently formed of organic material and are represented at the present day by the Ooze of the Atlantic Ocean.

The Chalk for the most part belongs to this class, as does the greater part of the Carboniferous Limestone, and some of the Silurian, Ordovician, and Cambrian Limestones.

We have seen something of many of these formations in recent years, but I do not propose to deal with them this evening.

\section{CLASS VIII.-CORAL REEFS.}

Probably many of our Jurassic strata are composed of the débris of coral reefs, but it is not easy to say to what extent we have the coral reefs themselves.

Speaking of the Coral Rag, Lyell remarked (" Elements of Geology," 6th edit., p. 395) that it consists in part of continuous beds of petrified corals, for the most part retaining the position in which they grew at the bottom of the sea. In their forms they more frequently resemble the reef-building poliparia of the Pacific than do the corals of any other member of the Oolite.

The celebrated quarries near Marcham, in Berkshire, were visited by the Association on April 19th, I892, and they have been described by Messrs. Blake and Hudleston (Quart. Journ. Geol. Soc., vol. xxxiii, pp. 305-308). In their account of the quarry at Bradley Farm, those authors say, "we have at the top about six feet of magnificent Rag, the massive portions growing in lenticular masses with bases not horizontal, and the intermediate spaces filled to a large extent with Thecosmilice. The reef-corals here are in a more perfect state of preservation than in any locality we know of, and leave little to be desired." On the other hand, Professor Blake considers that the masses of corals which are found in the Corallian at Hackness, in Yorkshire, are not in their place of growth, but are fragments torn from a reef elsewhere (Proc. Geol. Assoc., vol. xii, p. I35).

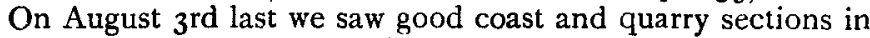
the rocks of the Scremerston Coal Series, which Mr. Goodchild told us was on the same geological horizon as part of the Mountain Limestone of North-west Yorkshire, and also contemporaneous with the oil shale series of the Edinburgh District. Now the former of these formations probably belongs to the Pelagic and the latter to the Estuarine class, so that we may be in some doubt as to the class in which we should place the various beds of the Scremerston Coal Series. The limestones are crowded with corals, but Mr. Goodchild said they were not reef-building forms and he did not consider that there was a coral reef in situ. 


\section{CLASS IX.-ABYSSAL DEPOSITS.}

It is probable that some of our Silurian, Ordovician, and Cambrian rocks were deposited in the depths of an ocean, and may be classed as Abyssal Deposits.

This matter was discussed to some extent during our Long Excursion last year. Our Director, Mr. Goodchild, said that the radiolarian chert of the Ordovician of the Tweed area agrees in all essential respects with the modern deep-sea radiolarian ooze, and he seemed to favour the idea that it had been deposited under similar conditions as to depth.

Mr. Horne has expressed a similar opinion with regard to some of the rocks of the Clyde basin. He says, "One prominent rock-group preserves, with rare exceptions, its uniform lithological character throughout the uplands. It consists of cherts and mudstones partly of Upper Arenig and partly of Lower Llandeilo age, which, where not deformed or altered by intrusive igneous masses, are richly charged with Radiolaria. The mudstones contain hingeless Brachiopods and other organisms. The cherts, which have been formed from a true radiolarian ooze, and the mudstones imply an oceanic phase of sedimentation." ("Brit. Assoc. Glasgow Handbook," I $9 \circ \mathrm{r}$, p. 403.)

I have not this evening time to enter more fully into these deep-sea deposits, and I can only thank you for the kind attention with which you have listened to my remarks, and now that I have completed my term of office as your President I desire to express my sincere appreciation of the honour you did me in electing me, and of the great kindness I have received from all the members of the Association during the past two years. I am more especially indebted to my fellow-officers, and I can assure them that I fully appreciate the large amount of time and work which they have given to our Association.

My successor needs no introduction to you. Dr. Smith Woodward, the Keeper of the Department of Geology at the British Museum, is not only well known to all of us here, but has a wide reputation as a geologist, both at home and abroad. $\mathrm{He}$ has always taken a keen interest in the Association, and I feel it a great honour to be succeeded by him as your President. 